\title{
Diversity and Abundance of Insects as Bioindicators of the Environmental Impacts of Tin Mining in Bangka Island, Indonesia
}

\author{
Keragaman dan Kelimpahan Serangga sebagai Bioindicators dari Dampak Lingkungan \\ Penambangan Timah di Pulau Bangka, Indonesia
}

\author{
Norela Sulaiman $^{1 *}$, Nila Sary ${ }^{2}$, and Maimon Abdullah ${ }^{1}$ \\ ${ }^{l}$ Pusat Pengajian Sains Sekitaran dan Sumber Alam, Fakultas Sains dan Teknologi \\ Universitas Kebangsaan Malaysia, 43600 Bangi Selangor, Malaysia \\ ${ }^{2}$ LPMP Kepulauan Bangka Belitung, Komplek Perkantoran Gubernur Air Itam Pangkalpinang-Bangka, Indonesia \\ E-mail: Mel-elektronik:vozela@ukm.my *Correspondence author
}

\begin{abstract}
A study was conducted to determine the effects of tin mining activities on the abundance and diversity of insects and screening of potential taxonomic groups as potential candidates for good environmental bioindicators. Samplings were conducted from 28 May-12 June 2008 at four selected study stations in Kampung Dul Bangka Tengah Provinsi Kepulauan Bangka Belitung. Two stations were sited in the tin mining areas (stations B1 and B2) while two control stations were sited in the surrounding undisturbed protected forest area (stations B3 and B4). Samplings were conducted using four methods, i.e. the yellow pan traps, sticky traps, light traps, sweeping nets and pitfall traps. A total of 3850 insect individuals representing 110 families and 493 morphospecies were identified, and Lepidoptera was found to be the largest insect order in the study area represented by the highest number of families. Mining activities have adversely affected the diversity and abundance of insects in the disturbed as compared to the undisturbed forested area. There were significant differences $(p<0.05)$ in the abundance of insects according to morphospecies between the four study stations, however, there were no significant correlations $(p>0.05)$ between the abiotic factors (soil $\mathrm{pH}$, soil humus, air temperatures and relative humidity) and insect abundance. The highest total of morphospecies was recorded for the family Noctuidae, while the most abundant individuals were from the family Formicidae. A total of 18 families were identified to have good potential as bioindicators, i.e. Culicidae, Syrphidae, Tipulidae, Alydidae, Cicadellidae, Formicidae, Gelechiidae, Arctiidae, Nymphalidae, Pteroporidae, Cosmopterigidae, Drepanidae, Geometridae and Noctuidae, Aeschinidae, Libellulidae, Tetrigidae and Tridactylidae.
\end{abstract}

Keywords: Diversity, abundance, tin tailing, insects, bioindicators

Abstrak

Satu kajian telah dijalankan untuk menentukan efek aktivitas pertambangan timah pada kelimpahan dan keragaman serangga dan memilih/menyaring kelompok taksonomi potensial sebagai kandidat potensial bagi bioindikator lingkungan yang baik. Pengambilan contoh dilakukan pada 28 Mei-12 Juni 2008 pada empat stasiun. Dua stasiun ditempatkan dalam daerah pertambangan (stasiun B1 dan B2) sementara dua stasiun control ditempatkan di sekitar daerah hutan lindung (stasiun B3 dan B4). Pengambilan contoh menggunakan empat metode uji perangkap piring kuning, perangkap lekat, perangkap cahaya, jarring sapuan, dan perangkap lubang. Sejumlah 3850 individu serangga memiliki 110 suku dan 493 morfospesies telah diidentifikasi, dan Lepidoptera ditemukan merupakan ordo serangga terbesar yang mewakili jumlah tertinggi. Aktivitas pertambangan telah mengakibatkan keragaman dan kelimpahan serangga terganggu dibandingkan dengan daerah hutan lindung. Terdapat perbedaan yang signifikan $(p<0,05)$ pada kelimpahan serangga mengikut morfospesies di antara keempat-empat stesen kajian, sebaliknya tiada korelasi signifikan $(p>0,05)$ faktor-faktor abiotik (pH, humus tanah, kelembapan relatif dan suhu udara) terhadap kelimpahan serangga. Jumlah morfospesies terbesar adalah pada suku Noctuidae, sedangkan individu paling melimpah adalah suku Formicidae. Sebanyak 18 suku telah diikenal berpotensi sebagai biopenunjuk yaitu: Culicidae, Syrphidae, Tipulidae, Alydidae, Cicadellidae, Formicidae, Gelechiidae, 
Arctiidae, Nymphalidae, Pteroporidae, Cosmopterigidae, Drepanidae, Geometridae dan Noctuidae, Aeschinidae, Libellulidae, Tetrigidae dan Tridactylidae.

Kata kunci: Keragaman, kelimpahan, bekas tambang, serangga, biopenunjuk 